\title{
Relasi Mahkamah Agung Dan Pengadilan Pajak Dalam Kekuasaan Kehakiman
}

\author{
Reni Ratna Anggreini \\ Magister Hukum Fakultas Hukum Universitas Islam Indonesia Yogyakarta Indonesia \\ Jln. Cik Di Tiro No. 1 Yogyakarta Indonesia \\ renyratna2795@gmail.com
}

\begin{abstract}
The purpose of this study is to examine and analyze the relationship between the Tax Court and the Supreme Court in Judicial Power. This is a normative legal research. The approach is a statutory approach. The results of this research conclude that the Supreme Court has a position as a supervisor and supervisor in the tax court, namely providing guidance to the technical courts in the Tax Court and supervising the duties of the judiciary and the behavior of judges. Whereas in judicial proceedings the Supreme Court does not have any authority in correcting the decisions of the first and second levels in the tax court, so it is necessary to reform the tax court law in terms of deciding on tax disputes only at the cassation level so that the Supreme Court has more authority in examining, adjudicate and decide on tax disputes within the judex juris area with the aim of providing legal justice for Taxpayers to take legal remedies for cassation.
\end{abstract}

Key Words: judicial review; supreme court; tax court

\begin{abstract}
Abstrak
Tujuan penelitian ini untuk mengkaji dan menganalisa relasi Pengadilan Pajak dan Mahkamah Agung dalam Kekuasaan Kehakiman. Metode penelitian ini adalah hukum normatif. Pendekatannya adalah pendekatan peraturan perundang-undangan (statue approach). Hasil penilitian ini menyimpulkan, Mahkamah Agung memiliki kedudukan sebagai pembina dan pengawas di dalam pengadilan pajak, yaitu melakukan pembinaan terhadap teknis peradilan di Pengadilan Pajak dan melakukan pengawasan terhadap tugas-tugas peradilan dan tingkah laku hakim. Sedangkan dalam acara peradilan Mahkamah Agung tidak memiliki kewenangan apapun dalam mengoreksi putusan tingkat pertama dan kedua dalam pengadilan pajak, sehingga perlu kiranya adanya pembaharuan dalam Undang-Undang peradilan pajak dalam hal memutus sengketa pajak hanya di tingkat kasasi agar Mahkamah Agung memiliki kewenangan lebih dalam memeriksa, mengadili dan memutus sengketa pajak dalam wilayah judex juris dengan tujuan memberikan keadilan hukum bagi Wajib Pajak untuk melakukan upaya hukum kasasi.
\end{abstract}

Kata-kata Kunci: Pengadilan pajak; mahkamah agung; peninjauan kembali 


\section{Pendahuluan}

Pelaksanaan pemungutan pajak-pajak oleh negara di Indonesia telah diatur dalam konstitusi negara. Dalam ilmu hukum, kita berbicara tentang pelaksanaan keadilan (administration of justice) yang berarti mengatur hubungan-hubungan dan menertibkan kelakuan manusia di dalam dan melalui pengadilan-pengadilan. Sebagai penyelenggara negara tidak dapat sewenang-wenang bertindak dalam hal memungut pajak dari rakyatnya, akan tetapi walau telah diatur dengan demikian, apakah dapat menjamin akan tercapainya suatu kepastian hukum dalam pemungutan pajak? Serta apakah dengan demikian juga telah terjamin akan terciptanya rasa keadilan dalam masyarakat pembayar pajak? ${ }^{1}$

Hal ini karena selain menjalankan kewajiban membayar pajak kepada negara atas dasar menaati peraturan perundang-undangan yang dibentuk oleh pemerintah tersebut, maka harus pula dibarangi dari kesadaran wajib pajak untuk membayar sesuai beban pajak yang harus dibayar, sehingga dalam konteks ini, wajib pajak harus jujur dalam melakukan pembayaran pajak, sehingga wajib pajak yang telah jujur membayar sejumlah beban pajak, pemerintah harus memberikan hak-hak apabila suatu ketika wajib pajak dirugikan, hak-hak tersebut tidak lain adalah tersedianya upaya hukum oleh wajib pajak untuk mendapatkan keadilan bagi dirinya yang telah menjalankan kewajibannya tersebut untuk menggugat di peradilan pajak, atau badan-badan peradilan yang dibentuk oleh konstitusi apabila dirugikan atas pelaksanaan kewajiban berdasarkan peraturan perundang-undangan mengenai perpajakan itu.

Secara yuridis, sebab akibat timbulnya sengketa perpajakan jika ditelaah satu persatu dalam pengertiannya menurut UU No. 14 Tahun 2002 tentang Pengadilan Pajak dapat ditarik kesimpulan bahwa sengketa itu muncul, diakibatkan karena dikeluarkannya suatu keputusan yang telah memenuhi persyaratan dapat diajukannya Banding atau Gugatan di Pengadilan Pajak berdasarkan perundang-undangan perpajakan, selain itu karena dalam pelaksanaan penagihan berdasarkan undang-undang penagihan pajak dengan surat paksa sehingga menimbulkan gugatan dari wajib pajak.

Substansi dalam Undang-Undang tersebut memberikan kesempatan kepada warga negara yang tidak puas terhadap suatu keputusan (beschikking) yang dikeluarkan oleh pemerintah untuk mengajukan banding apabila:

a. Suatu keputusan bertentangan dengan peraturan umum yang berlaku;

1 Agus S Suryadi, “Hukum Pajak Menghendaki Pemungkutan Hukum,” Law Review V, No. I, 2005, hlm. 338-352 dan hlm. 341-342 
b. Badan yang melaksanakan suatu wewenang yang diberikan melaksanakan wewenang tersebut lain daripada maksud dari tujuan diberikannya wewenang itu (de tournement de pouvoir);

c. Badan tersebut dalam mempertimbangkan kepentingan yang bersangkuatan tidak membuat keputusan yang patut/ sewenang-wenang (wilikeur / a bus de droit);

d. Badan tersebut telah berbuat bertentangan dengan kesadaran dan AAUPL. ${ }^{2}$

Sejalan dengan itu, berdasarkan Undang-Undang No. 17 Tahun 1997 dibentuk Badan Penyelesaian Sengketa Pajak (BPSP). Badan ini merupakan suatu badan yang seolah-olah menjalankan fungsi peradilan yang menangani sengketa perpajakan, namun tidak berpucak kepada Mahkamah Agung. Oleh karena itu, pembinaan organisasi dari keuangan BPSP dilakukan oleh Departemen Keuangan, maka BPSP lebih tepat disebut sebagai peradilan tidak murni atau peradilan semu (quasi). Akhirnya, sejak 2002 dibentuk Peradilan Pajak sebagai peradilan khusus. Peradilan Pajak sebagai Peradilan khusus dibentuk dengan Undang-Undang No. 14 Tahun 2002 tentang Pengadilan Pajak. ${ }^{3}$

Tugas dan wewenang pengadilan pajak pada umumnya diberikan wewenang dalam memeriksa dan memutus sengketa pajak, yaitu apabila terdapat banding maka pengadilan pajak memeriksa dan memutus sengketa tersebut atas keputusan keberatan, kecuali ditentukan oleh peraturan perundangundangan yang berlaku. Pengadilan Pajak dalam hal gugatan tersebut wajib memeriksa dan memutus sengketa atas pelaksanaan penagihan pajak atau keputusan pembetulan atau keputusan lainnya. ${ }^{4}$

Persoalannya, Pengadilan Pajak dinyatakan sebagai pengadilan tingkat pertama dan terakhir dalam memeriksa dan memutus sengketa pajak. Dalam hal putusan Pengadilan Pajak itu tidak dapat diajukan gugatan ke Peradilan Umum, Peradilan Tata Usaha Negara, atau badan peradilan lain, kecuali putusan berupa "tidak dapat diterima" yang menyangkut kewenangan/kompetensi, namun dapat diajukan Peninjauan Kembali kepada Mahkamah Agung. Meskipun dilakukan pengajuan keberatan namun pengajuan keberatan tidak menunda kewajiban pembayaran pajak dan pelaksanaan penagihan pajak. ${ }^{5}$

Berdasarkan penelusuran penulis melalui Direktori Putusan Mahkamah Agung Republik Indonesia terdapat beberapa putusan di tahun 2018 mengenai pengajuan Peninjauan Kembali baik dari orang perorangan/badan hukum atau

\footnotetext{
${ }^{2}$ S.F. Marbun, Asas-Asas Umum Pemerintahan Yang Layak, FH UII Press, Yogyakarta, 2014, hlm. 47

${ }^{3}$ Marbun, Hukum Adminsitrasi..., Op. Cit., hlm.. 491.

4 Pasal 31 ayat (1) (2) (3) "Undang-Undang Republik Indonesia Nomor 14 Tahun 2002 tentang Pengadilan Pajak" (2002).

${ }^{5}$ Marbun, Asas-Asas Umum.., Op. Cit., hlm. 492.
} 
dari kantor pelayanan pajak/direktorat pajak. Temuan tersebut dapat dilihat dalam bentuk tabulasi sebagai berikut:

Tabel. 1 Putusan MA dalam Permohonan Peninjauan Kembali Sengketa Pajak

\begin{tabular}{|c|c|c|}
\hline & Nomor Putusan PK & Putusan Hakim MA \\
\hline & $\begin{array}{l}\text { Putusan Nomor } \\
\text { 358/B/PK/Pjk/2018 }\end{array}$ & $\begin{array}{l}\text { Mengabulkan permohonan peninjauan kembali dar } \\
\text { Pemohon Peninjauan Kembali }\end{array}$ \\
\hline & $\begin{array}{l}\text { Putusan Nomor } \\
2913 / \mathrm{b} / \mathrm{pk} / \mathrm{pjk} / 2018\end{array}$ & $\begin{array}{l}\text { Menolak permohonan peninjauan kembali dar } \\
\text { Pemohon Peninjauan Kembali }\end{array}$ \\
\hline 3 & $\begin{array}{l}\text { Putusan Nomor } \\
\text { 326/B/PK/Pjk/2018 }\end{array}$ & $\begin{array}{l}\text { Mengabulkan permohonan peninjauan kembali dar } \\
\text { Pemohon Peninjauan Kembali }\end{array}$ \\
\hline & $\begin{array}{l}\text { Putusan Nomor } \\
\text { 2913/B/PK/Pjk/2018 }\end{array}$ & $\begin{array}{l}\text { Menolak permohonan peninjauan kembali dari } \\
\text { Pemohon Peninjauan Kembali }\end{array}$ \\
\hline & $\begin{array}{l}\text { Putusan Nomor } \\
\text { 358/B/PK/Pjk/2018 }\end{array}$ & $\begin{array}{l}\text { Mengabulkan permohonan peninjauan kembali dari } \\
\text { Pemohon Peninjauan Kembali }\end{array}$ \\
\hline 6 & $\begin{array}{l}\text { Putusan Nomor } \\
\text { 283/B/PK/Pjk/2018 }\end{array}$ & $\begin{array}{l}\text { Mengabulkan permohonan peninjauan kembali dari } \\
\text { Pemohon peninjauan kembali }\end{array}$ \\
\hline & $\begin{array}{lr}\text { Putusan } & \text { Nomor } \\
1617 / \mathrm{B} / \mathrm{PK} / \mathrm{Pjk} / 2018\end{array}$ & $\begin{array}{l}\text { Mengabulkan permohonan peninjauan kembalidari } \\
\text { Pemohon Peninjauan Kembali }\end{array}$ \\
\hline
\end{tabular}

Sumber : Direktori Putusan Mahkamah Agung Republik Indonesia

Upaya hukum yang dapat ditempuh setelah Putusan Pengadilan Pajak hanyalah upaya Peninjauan Kembali. Hal ini secara implisit berarti adanya reduksi atau pengurangan fungsi yudikatif dalam sistem peradilan pajak. Bahwa eksistensi (fungsi) pengadilan pajak menurut UU PP tidak berlaku dengan sistem peradilan yang berlaku karena peradilan pajak tidak menerapkan upaya hukum pada tingkat kasasi. Karena itu, MA sebagai lembaga judicial control tertinggi tidak dapat menggunakan kewenangannya secara optimal dalam Peradilan Pajak. ${ }^{6}$

Pada acara sengketa di pengadilan pajak, memberikan sedikit kesempatan untuk melakukan peninjauan kembali atas upaya hukum luar biasa dari penggugat atau tergugat di MA, tetapi tidak memberikan kewenangan untuk mengadili, memeriksa dan memutus sengketa pajak dalam upaya hukum biasa seperti kasasi di pengadilan umum atau pengadilan khusus yang mencakup dalam peradilan yang berada di bawah MA. Sehingga perlu kiranya dilihat kedudukan MA dalam kekuasaan kehakiman di Indonesia dalam pengadilan pajak dan kewenangan MA terkait penyelesaian sengketa pajak dalam upaya hukum peninjauan kembali di MA.

${ }^{6}$ Wan Juli, "Hak Dan Kewajiban Wajib Pajak Dalam Penyelesaian Sengketa Perpajakan Di Pengadilan Pajak,” Perspektif XIX, No. 3 (2014), hlm. 199. 
Penelitian terdahulu terkait kedudukan dan kewenangan MA dalam acara peradilan pajak di Indonesia, dapat cermati dari hasil penelusuran penulis, jika terdapat beberapa tema yang hampir sama dengan penulis yang akan bahas, yaitu akan dijabarkan lebih lanjut mengenai tema-tema tersebut yang pernah dilakukan oleh beberapa penulis lain.

Pertama, sengketa perpajakan dalam perspektif kekuasaan kehakiman yang ditulis oleh Heru Suyanto dan Suherman pada 2015.7 Penelitian ini berfokus pada keberadaan Pengadilan Pajak telah ditegaskan dalam Undang-Undang Nomor 14 Tahun 2002 tentang Pengadilan Pajak yang mempunyai kewenangan untuk memeriksa dan memutus perkara tentang sengketa pajak, namun adanya beberapa karakteristik dari Pengadilan Pajak yang tidak sinergis dengan Peradilan Tata Usaha Negara masih menyisakan perdebatan akan status keberadaan Pengadilan Pajak dalam sistem kekuasaan kehakiman di Indonesia. Hasil penelitiannya ditemukan jika pada subyek sengketa terdapat sedikit perbedaan dikarenakan Peradilan Tata Usaha Negara hanya mengakui orang dan badan hukum perdata saja yang dapat mengajukan perkaranya untuk diperiksa. Sedangkan Pengadilan Pajak juga mengakui Bentuk Usaha Tetap sebagai salah satu subyek yang. Namun hal ini tidaklah terlalu tepat dikarenakan tidak ada satupun pasal di Undang-Undang Nomor 14 Tahun 2002 yang menyiratkan bahwa Pengadilan Pajak adalah pengadilan tersendiri. Selain itu bukanlah hal yang tabu bila kita merubah 4 lingkup peradilan seperti sekarang ini bila kondisi sosial masyarakat menuntut hal ini. Keempat lingkup peradilan yang kita anut bukan bentuk baku namun hal ini memang akan merombak peraturan perundang-undanganyang menjadi payung pada sistem kekuasaan kehakiman di Indonesia. Kesiapan infrastruktur, sosiologis, dan sumber daya manusia harus diperhitungkan dalam hal ini.dapat mengajukan perkara untuk diperiksa di Pengadilan Pajak.

Kedua, Kedudukan, Eksistensi dan Independensi Pengadilan Pajak dalam Kekuasaan Kehakiman Di Indonesia yang ditulis oleh Afdol Sylvia Setjoatmadja pada 2015. 8 Penelitian ini berfokus kedudukan pengadilan pajak dalam kekuasaan kehakimandi Indonesia adalah, bahwa Pengadilan Pajak merupakan badan peradilan khusus di lingkungan peradilan Tata Usaha Negara, namun demikian tidak murni sebagai badan peradilan yang melaksanakan kekuasaan kehakiman, karena terdapat tugas-tugas eksekutif yang dilaksanakan oleh Pengadilan Pajak. Hasil penelitian ini menjabarkan mengenai eksistensi dan

${ }^{7}$ Heru Suyanto, “Sengketa Perpajakan Dalam Perspektif Kekuasaan,” Yuridis 2, No. 1, 2015, hlm. 95110.

8 Afdol Sylvia Setjoatmadja, "Kedudukan, Eksistensi Dan Indepedensi Pengadilan Pajak Dalam Kekuasaaan Kehakiman Di Indonesia,” Jurnal Hukum Bisnis 1, No. 1, 2015. 
independensi pengadilan pajak, bahwa Pengadilan Pajak yang merupakan pengadilan tingkat banding sesuai dengan Ilmu Hukum yang berlaku secara universal, sebagaimana dalam ketentuan Pasal 27 UU Kekuasaan Kehakiman ditegaskan dimana Pengadilan Pajak merupakan bagian dari Peradilan Tata Usaha Negara (PTUN), dan sebagai pengadilan yang bersifat khusus sudah selayaknya memiliki hukum acara tersendiri, dimana setiap badan pengadilan mempunyai hukum acara sendiri yang merupakan panduan bagi para penegak hukum dan hakim untuk menjalankan kekuasaan kehakiman, sedangkan indenpendensi jika dicermati beberapa pasal yang termuat di dalam UU 14 Tahun 2002 tentang Pengadilan Pajak, maka nampaknya Pengadilan Pajak memiliki sifat kemandirian yang berdiri sendiri terpisah dari Mahkamah Agung, hal ini dapat terlihat dari sifat dan jenis putusan serta rekrutmen para Hakim Pengadilan Pajak.

Pada penelitian yang dilakukan oleh Heru Suyanto dan Suherman, secara garis besar penelitiannya tersebut lebih menekankan pada perbedaan sengketa antara Pengadilan Pajak dan Pengadilan Tata Usaha Negara (PTUN) secara normatif atau berdasarkan peraturan perundang-undangandi Indoneisia, serta menjelaskan perbedaan subyek hukum yang dapat melakukan sengketa.

Pada penelitian Afdol Sylvia Setjoatmadja, menjelaskan eksistensi dan independensi Pengadilan Pajak dengan menjabarkan proses beracara di Pengadilan Pajak dengan memuat norma-norma peraturan perundangundanganmengenai kekuasaan kehakiman, di mana Pengadilan Pajak memiliki bersifat mandiri yang berdiri sendiri terpisah dari Mahkamah Agung karena sifat dan jenis putusan serta rekrutmen pada Hakim Pengadilan Pajak.

Pada penelitian ini, penulis lebih berfokus kedudukan MA sebagai pengawas dan sekaligus kedudukannya sebagai pembina dalam pengadilan. Sedangkan penelitian ini akan melihat dari segi administratif dalam organisasi dan pengangkatan struktural peradilan. Kemudian dalam hal kewenangan dalam proses beracara, penulis akan melihat fungsinya sebagai lembaga terakhir dalam memberikan kesempatan bagi masyarakat untuk melakukan upaya hukumnya.

Pada kedudukan dan kewenangan MA dalam menjalankan fungsi judicialnya sebagai lembaga dalam kekuasaan yudikatif dalam menyelesaikan sengketa hukum di tengah masyarakat.

\section{Rumusan Masalah}

Pada penelitian ini, permasalahan yang di rumuskan berdasarkan uraian di atas, adalah bagaimana relasi Pengadilan Pajak dan Mahkamah Agung dalam kekuasaan kehakiman dan apa kewenangan Mahkamah Agung terkait penyelesaian sengketa pajak dalam sistem perpajakan Indonesia. 


\section{Tujuan Penelitian}

Untuk menganalisis relasi Mahkamah Agung dan Pengadilan Pajak dalam kekuasaan kehakiman dan serta mengkaji secara mendalam kewenangan Mahkamah Agung terkait penyelesaian sengeketa pajak dalam sistem perpajakan Indonesia.

\section{Metode Penelitian}

Metode penelitian ini merupakan suatu penelitian hokum, ${ }^{9}$ yaitu penelitian yang mengkaji pada peraturan tertulis yang memuat norma hukum yang mengikat secara umum dan dibentuk atau ditetapkan oleh lembaga negara atau pejabat yang berwenang melalui prosedur yang ditetapkan dalam peraturan perundang-undangan. ${ }^{10}$ Dengan kata lain, penelitian hukum normatif adalah argumentasi hukum. Oleh karena itu, penalaran hukum (legal reasoning) dalam penelitian hukum normatif penting pula keberadaannya atau kedudukannya. Melalui penalaran hukum diharapkan langkah-langkah kajian hukum dapat sesuai dengan maksud dan tujuan penelitian. Kajian hukum normatif adalah suatu proses nalar (berpikir). ${ }^{11}$

Pendekatan yang digunakan dalam penelitian ini adalah pendekatan peraturan perundang-undangan (statue approach) yang berhubungan dengan tema pada penelitian ini. Dengan melakukan pengumpulan data melalui studi kepustakaan merupakan metode tunggal yang dipergunakan dalam penelitian normatif. Bahan hukumnya bersumber pada buku, kertas konferensi, laporan penelitian, laporan teknis, majalah, disertasi dan tesis, paten.12 Selanjutnya, data primer dan sekunder dikumpulkan, selanjutnya kategorisasikan, diklarifikasikan, ditabulasikan dan diinterpretasikan, serta kemudian dianalisis datanya atau melakukan analisis bahan hukum (untuk penelitian hukum normatif).13

\section{Hasil Penelitian dan Pembahasan}

\section{Mahkamah Agung dan Pengadilan Pajak}

Usaha memperkuat prinsip kekuasaan kehakiman yang merdeka sesuai dengan tuntutan reformasi di bidang hukum telah dilakukan perubahan terhadap UU No. 14 Tahun 1970 tentang Kekuasaan Kehakiman dengan UU No. 35 Tahun 1999 tentang Perubahan atas UU No. 14 Tahun 1970 tentang Ketentuan-ketentuan

\footnotetext{
${ }^{9}$ Bambang Sunggono, Metode Penelitian Hukum, Ke 14, PT Grafindo Persada, Jakarta, 2013, hlm. 86

${ }^{10}$ Ibid., hlm. 137.

11 Ibid., hlm. 13.

12 Suratman dan Philips Dillah, Metode Penelitian Hukum, Ketiga, Alfabeta, Bandung, 2015, hlm. 123

${ }^{13}$ Sunggono, Metode Penelitian..., Op. Cit., hlm. 107.
} 
Pokok Kekuasaan Kehakiman, dan telah dicabut dengan UU No. 4 Tahun 2004 tentang Kekuasaan Kehakiman sejak 29 Oktober 2009, UU No. 4 Tahun 2004 telah dicabut dan dinyatakan tidak berlaku oleh UU No. 48 Tahun 2009 tentang Kekuasaan Kehakiman (Lembaran Negara RI Tahun 2009 Nomor 1567), melalui perubahan tersebut telah diletakkan kebijakan bahwa segala urusan mengenai perorganisasian, administrasi, dan finansial berada di bawah satu atap di bawah kekuasaan Mahkamah Agung. Hal ini dianggap penting dalam rangka perwujudan kekuasaan kehakiman yang menjamin tegaknya negara hukum yang didukung oleh sistem kekuasaan kehakiman yang 'independen' dan 'impartial.14

Berdasarkan ketentuan undang-undang Kekuasaan kehakiman, pemegang kekuasan kehakiman adalah Mahkamah Konstitusi. Badan peradilan di bawah Mahkamah Agung adalah lingkungan Peradilan Umum, Agama, Militer dan Tata Usaha Negara. Artinya, jika benar bahwa Pengadilan Pajak merupakan lembaga peradilan yang di bawah Mahkamah Agung, Pengadilan Pajak tentu harus masuk ke dalam salah satu dari empat lingkungan peradilan yang ada. Dari pengaturan yang ada dalam Undang-Undang Kekuasaan Kehakiman, tampak bahwa semua peroalan hukum yang dihadapi oleh siapapun di negeri ini, apabila tidak menjadi kompetensi dari Mahkamah Konstitusi dan akan diselesaikan melalui jalur peradilan, harus dapat diselesaikan di pengadilan dari lingkungan peradilan yang ada di bawah Mahkamah Agung. Bahkan, Pasal 15 ayat (1) Undang-Undang Kekuasaan Kehakiman menyatakan bahwa peradilan khusus hanya dapat dibentuk dalam salah satu lingkungan peradilan sebagaimana dimasud dalam Pasal 10 yang diatur dengan Undang-Undang. Dengan demikian, mestinya tidak ada pengadilan di luar empat lingkungan peradilan yang ada di bawah Mahakamh Agung. ${ }^{15}$

Apabila mengacu Undang-Undang Republik Indonesia Nomor 48 Tahun 2009 tentang Kekuasaan Kehakiman Pasal 27 ayat (1) menjelaskan, Pengadilan khusus hanya dapat dibentuk dalam salah satu lingkungan peradilan yang berada di bawah Mahkamah Agung sebagaimana dimaksud dalam Pasal 25. Penjelasan dari Pasal 27 ayat (1): Yang dimaksud dengan "pengadilan khusus" antara lain adalah pengadilan anak, pengadilan niaga, pengadilan hak asasi manusia, pengadilan tindak pidana korupsi, pengadilan hubungan industrial dan pengadilan perikanan yang berada di lingkungan peradilan umum, serta pengadilan pajak yang berada di lingkungan peradilan tata usaha negara.

${ }^{14}$ Ni’Matul Huda, Hukum Tata Negara Indonesia Edisi Revisi, PT Raja Grafindo Persada, Jakarta, 2014, hlm.

15 Tjia Siauw Jan, Pengadilan Pajak Upaya Kepastian Hukum Dan Keadilan Bagi Wajib Pajak, Ke-I, PT ALUMNI, Bandung, 2013, hlm. 119 
Pengadilan pajak dianggap sebagai pengadilan khusus yang masih berada di bawah Mahkamah Agung, maka terlihat jika harusnya peradilan pajak tidak lepas dari pengawasan yang dilakukan oleh Mahkamah Agung. Hal demikian karena dalam acara peradilan pajak tidak menutup kemungkinan apabila dasar negara hukum dan demokrasi di dalam kekuasaan kehakiman yang merdeka atau bebas tidak memiliki batasan konstitusional seperti independennya pengadilan pajak sebagai badan peradilan tingkat pertama dan terakhir dalam upaya hukum wajib pajak. Karenanya pengadilan pajak di bawah pemerintah harus adil dan melepaskan pengaruhnya dalam sistem peradilan Indonesia.

Menyimak hal di atas, MA tetap memiliki kedudukan yang tinggi di atas semua peradilan yang ada. Hal ini mengacu Bab IX kekuasaan kehakiman Pasal 24 ayat (2) bahwa, Kekuasaan kehakiman dilakukan oleh sebuah Mahkamah Agung dan badan peradilan yang berada di bawahnya dalam lingkungan peradilan umum, lingkungan peradilan agama, lingkungan peradilan militer, lingkungan peradilan tata usaha negara, dan oleh sebuah Mahkamah Konstitusi.

Berdasarkan bagian di atas, maka tentunya ada campur tangan MA selain dari upaya hukum luar biasa (peninjauan kembali). Secara yuridis, campur tangan yang dimaksud adalah berupa pembinaan terhadap pengadilan pajak. Antara lain:

1) Pembinaan teknis peradilan bagi Pengadilan Pajak dilakukan oleh Mahkamah Agung;

2) Pembinaan organisasi, administrasi, dan keuangan bagi Pengadilan Pajak dilakukan oleh Departemen Keuangan;

3) Pembinaan tidak boleh mengurangi kebebasan Hakim dalam memeriksa dan memutus Sengketa Pajak. ${ }^{16}$

Pada hakikatnya, apabila mengacu pada peradilan independen dan tidak memihak maka apa yang disebutkan dalam pembinaan yang dilakukan oleh MA sebenarnya menjadi keharusan agar memberikan keadilan bagi wajib pajak. Menurut yang dijelaskan oleh konstitusi Indonesia, peradilan yang bebas termuat dalam Pasal 24 ayat (1) UUD 1945, Kekuasaan Kehakiman merupakan kekuasaan yang merdeka untuk menyelenggarakan peradilan guna menegakkan hukum dan keadilan.

Menurut Bagir Manan, secara kebahasan (gramatikal), dibedakan antara "menegakkan hukum" dan "menegakkan keadilan". Pendirian semacam ini, pernah ada di kalangan kaum positifisme hukum (legal positivism). Menurut satu kelompok positifs: pertama, hukum tidak ada kaitannya dengan keadilan. Kedua; suatu kaidah hukum positif yang telah dibuat dengan tata cara yang benar, mesti

\footnotetext{
${ }^{16}$ Pasal 5 Undang-Undang Republik Indonesia Nomor 14 Tahun 2002 tentang Pengadilan Pajak.
} 
diterapkan meskipun bertentangan dengan rasa keadilan. Rumusan yang lazim adalah "untuk menegakkan hukum yang adil" atau "demi keadilan. ${ }^{17}$

Kedudukan MA dalam pengadilan Pajak Menurut UU Nomor 14 Tahun 2002 tentang Pengadilan Pajak berdasarkan pembinaan dan pengawasan yang dilakukan oleh MA di dalam sistem Pengadilan Pajak dapat dilihat dalam tabulasi sebagai berikut:

Tabel. 2 Pembinaan dan Pengawasan MA terhadap Peradilan Pajak

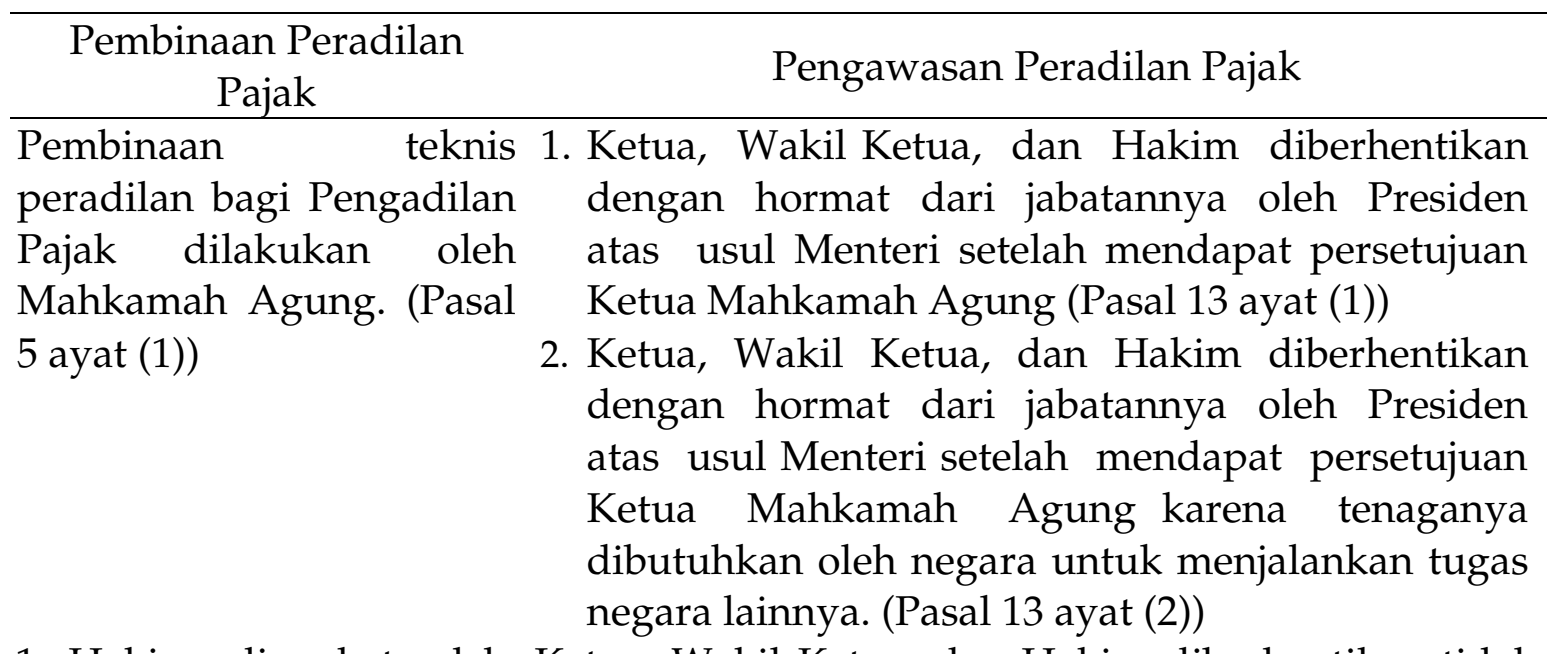

1. Hakim diangkat oleh Ketua, Wakil Ketua, dan Hakim diberhentikan tidak Presiden dari daftar dengan hormat dari jabatannya oleh Presiden atas nama calon yang usul Menteri, setelah mendapat persetujuan Ketua diusulkan oleh Mahkamah Agung (Pasal 14)

Menteri setelah mendapat persetujuan Ketua Mahkamah Agung.

2. Ketua dan Wakil Ketua diangkat oleh Presiden dari para Hakim yang diusulkan Menteri setelah mendapat persetujuan Ketua Mahkamah Agung. (Pasal 8)

Pembinaan pengawasan dan Ketua, Wakil Ketua, dan Hakim sebelum terhadap Hakim dilakukan sementara oleh Presiden atas usul Menteri dengan oleh Mahkamah Agung. persetujuan Ketua Mahkamah Agung. (Pasal 17 ayat (Pasal 11 ayat (1)) (1))

17 Bagir Manan, "Prasyarat Kemerdekaan Kekuasaan Kehakiman, Makalah Disampaikan Kuliah Umum Mahasiswa Magister Ilmu Hukum Universitas Islam Indonesia”, Yogyakarta, 2018, hlm. 2 
Pembentukan, susunan, 1. Ketua, Wakil Ketua, atau Hakim dapat ditangkap dan tata kerja Majelis dan/atau ditahan hanya atas perintah Jaksa Kehormatan Hakim serta Agung setelah mendapat persetujuan Presiden. tata cara pembelaan diri 2. Pelaksanaan penangkapan atau penahanan Hakim ditetapkan dengan Keputusan Presiden atas usul Ketua Mahkamah Agung dan Menteri. (Pasal 16 ayat (1))

Pembinaan teknis Panitera dilakukan oleh Mahkamah Agung. (Pasal 29 ayat (5))

Berdasarkan tabulasi di atas, pembinaan terhadap Pengadilan Pajak dilakukan oleh 2 lembaga, yaitu: Pembinaan teknis peradilan dan pembinaan serta pengawasan umum terhadap hakim dilakukan oleh Mahkamah Agung, sedangkan pembinaan organisasi, administrasi, dan keuangan dilakukan oleh Departemen keuangan. ${ }^{18}$ Apabila di fahami pada bagan 2 di atas, maka sebetulnya yang dilakukan oleh MA hanya sebatas pengawasan dan pembinaan secara tidak langsung. Karena demikian, sifatnya hanya laporan, persetujuan dan usul hanya bersifat tertulis atau hanya sebatas lisan. Padahal, Undang-Undang Republik Indonesia Nomor 48 Tahun 2009 tentang Kekuasaan Kehakiman Pasal 21 ayat (1) berbunyi, Organisasi, administrasi, dan finansial Mahkamah Agung dan badan peradilan yang berada di bawahnya berada di bawah kekuasaan Mahkamah Agung.

Jika dibandingkan dengan pengawasan dan pembinaan yang dilakukan MA pada peradilan yang berada di bawahnya, sangat berbeda dengan kewenangan mengawasi dan membina di wilayah peradilan pajak. Menurut Peraturan Mahkamah Agung Republik Indonesia Nomor 8 Tahun 2016 tentang Pengawasan dan Pembinaan Atasan Langsung di Lingkungan Mahkamah Agung dan Badan Peradilan di bawahnya. Dapat di fahami sebagai berikut:

1. Pengawasan dilaksanakan paling sedikit dengan:

a. Memantau, mengamati dan memeriksa pelaksanaan tugas agar berjalan sesuai dengan rencana dan ketentuan yang berlaku secara berdayaguna dan berhasil guna;

b. Meminta laporan dan pertanggungjawaban atas pelaksanaan tugas bawahan;

c. mengidentifikasi dan menganalisis gejala-gejala dan penyimpangan serta kesalahan yang terjadi, menentukan sebab dan akibatnya serta cara mengatasinya;

${ }^{18}$ Marbun, Hukum Adminsitrasi..., Op. Cit., hlm. 491. 
d. Merumuskan tindak lanjut dan mengambil langkahlangkah yang tepat sesuai dengan kewenangannya dengan memperhatikan kewenangan pejabat/instansi yang terkait; dan

e. Berkonsultasi kepada atasan langsungnya secara berjenjang dalam rangka meningkatkan mutu pengawasan yang dilakukannya.

2. Pembinaan dilaksanakan dengan:

a. Menjelaskan pembagian tugas, fungsi dan kewenangan bawahan dalam struktur organisasi di bawah kendalinya secara berkala;

b. Menetapkan dan menyetujui sasaran kinerja bawahan serta memberikan penilaian dan evaluasi terhadap pelaksanaan tugas capaian kinerja bawahan;

c. Menjelaskan, membuat dan menyepakati prosedur atau cara pelaksanaan pekerjaan atau kegiatan yang dinilai kurang jelas atau belum diatur secara khusus; dan

d. Membina bawahan agar dapat melaksanakan tugas dengan baik.

Menurut Prajudi Atmosudirjo dikutip oleh Adam Setiawan, pengawasan adalah proses kegiatan-kegiatan yang membandingkan apa yang dijalankan, dilaksanakan atau diselenggarakan itu dengan apa yang dikehendaki, direncanakan atau diperintahkan. Hasil pengawasan harus dapat menunjukan sampai di mana terdapat kecocokan atau ketidakcocokan, dan apakah sebab-sebabnya. Dengan demikian, maka pengawasan dapat bersifat: (1) politik, bilamana yang menjadi ukuran atau sasaran adalah effektifitas dan atau legitimasi; (2) yuridis (hukum), bilamana tujuannya adalah menegakan yuridikitas dan atau legalitas; (3) ekonomis bilamana yang menjadi sasaran adalah effisiensi dan teknologi; (4) moral dan susila, bilamana yang menjadi sasaran atau tujuan adalah mengetahui keadaan moralitas. $($ moral $=$ morals $;$ moril $=$ morale $) .19$

Terkait pembinaan dan pengawasan yang dilakukan oleh MA. Menurut Jamal Wiwoho, dari ketentuan di atas dapat diketahui bahwa adanya dualisme dalam melakukan pembinaan dan pengawasan terhadap lembaga peradilan. Pertama, administrasi dan keuangan, sedangkan pengawasan menyangkut kedudukan hakim sebagai pegawai negeri. Kedua, Mahkamah Agung menyangkut teknis peradilan dan pengawasan tertinggi atas pelaksanaan tugastugas peradilan seperti tingkah laku hakim. ${ }^{20}$

Pengadilan pajak menjadi bagian dari kementerian keuangan yang membawahi direktorat jenderal pajak, atau dengan kata lain masih di lingkungan eksekutif bukan lingkungan yudikatif. Sifat khusus ini menjadikan pengadilan

19 Adam Setiawan, "Eksistensi Lembaga Pengawasan Pengelolaan Keuangan Negara," Jurnal Hukum \& Pembangunan 49, No. 2 (2019), hlm. 270.

20 Jamal Wiwoho, Membangun Model Penyelesaian Sengketa Pajak Yang Berkeadilan, Lembaga Pengembangan Pendidikan UNS Dan UPT Penerbitan dan Percetakan UNS Press, Surakarta, 2008, hlm. 142 
pajak di luar dari ruang lingkup badan peradilan biasanya, karena sifat khususnya inilah dan bersifat mandiri menjadikannya sebuah badan peradilan di luar dari kekuasaan kehakiman. Karena demikian, hal ini selain rawan konflik kepentingan juga bertentangan dengan prinsip pemisahan kekuasaan bahwa kekuasaan eksekutif harus terpisah dengan kekuasaan yudikatif. Namun demikian, masalah campur tangan kekuasaan eksekutif dalam lingkup kekuasaan yudikatif memang merupakan permasalahan inheren praktik serta penegakan hukum di Indonesia. ${ }^{21}$

Pengadilan dengan struktur yang otonom menunjukkan bahwa pengadilan tersebut dapat mengatur dan membuat kebijakan sendiri baik di bidang finansial maupun di bidang yustisial. Kelulusan untuk mengatur diri sendiri tanpa berpengaruh dan dipengaruhi oleh lembaga lain adalah cerminan kemandirian lembaga peradilan sebagai struktur yang tak terpisahkan dengan lembaga eksekutif. Dalam beberapa hal berkaitan dengan struktur lembaga peradilan, khususnya di bidang pengangkatan, kepangkatan dan finansial adalah masih menjadi kewenangan eksekutif yang belum dilimpahkan sepenuhnya kepada lembaga peradilan untuk mengaturnya. ${ }^{22}$

\section{Kewenangan Mahkamah Agung dalam Peninjauan Kembali Penyelesaian Sengeketa Pajak}

Pemahaman pajak dari prespektif hukum merupakan suatu perikatan yang timbul karena adanya undang-undang yang menyebabkan timbulnya kewajiban warga negara untuk menyetorkan sejumlah penghasilan tertentu kepada negara, negara mempunyai kekuatan untuk memaksa, dan uang pajak tersebut harus digunakan untuk menyelenggarakan pemerintahan. Pendekatan hukum ini memperlihatkan bahwa setiap pajak yang akan dipungut haruslah berdasarkan Undang-Undang. Ketentuan ini diatur dalam Pasal 23A Undang-Undang Dasar Negara Republik Indonesia Tahun 1945 yang berbunyi : "Pajak dan pungutan lain yang bersifat memaksa untuk keperluan negara diatur dengan Undang-Undang". Sehingga dengan adanya ketentuan ini dapat menjamin adanya kepastian hukum, baik bagi fiskus sebagai pengumpul pajak maupun wajib pajak sebagai pembayar pajak.

Mengenai definisinya, banyak sarjana yang merumuskannya dengan rumusan yang berbeda-beda. Rochmat Soemitro dalam bukunya "Dasar-dasar Hukum Pajak dan Pajak Pendapatan" memberikan definisi bahwa pajak adalah iuran rakyat kepada kas negara berdasarkan Undang-Undang (yang dapat

\footnotetext{
${ }^{21}$ Wan Juli, "Hak Dan Kewajiban..., Op. Cit., hlm. 194.

${ }^{22}$ Jamal Wiwoho, Membangun Model Penyelesaian Sengketa Pajak. Yang Berkeadilan...., Op. Cit., hlm. 130-131.
} 
dipaksakan) dengan tiada mendapat jasa timbal (kontra prestasi) yang langsung dapat ditunjukkan dan yang dipergunakan untuk membayar pengeluaran umum. $^{23}$

Di Indonesia keadilan yang diikuti dalam pemungutan pajak adalah keadilan "umum dan merata". Karena kebijakan tersebut tidak akan menimbulkan diskriminasi, baik dari aspek sosial ekonomi, keyakinan, maupun status kewarganegaraan. Hal tersebut terlihat dari Pasal 1 ayat (1) UndangUndang Nomor 6 Tahun 1983 jis Undang-Undang Nomor 9 Tahun 1994, UndangUndang Nomor 16 Tahun 2000, Wajib Pajak adalah : "orang pribadi atau badan hukum yang menurut ketentuan peraturan perundang-undanganperpajakan, termasuk pemungutan pajak atau pemotong pajak tertentu". Ketetapan Pasal 1 ayat (1) ini dikuatkan oleh penjeleasan Pasal 16B ayat (1) yang menegaskan bahwa salah satu prinsip yang harus dipegang teguh dalam Undang-Undang Pajak adalah diberlakukan dan diterapkan perlakuan yang sama terhadap semua Wajib Pajak atau terhadap kasus-kasus dalam bidang perpajakan yang pada hakekatnya sama dengan berpegang teguh pada ketentuan perundangundanganyang berlaku. Ketentuan ini bertujuan untuk mencegah diskriminasi dalam pemungutan pajak. ${ }^{24}$

Setiap wajib pajak mempunyai hak-hak yang antara lain: a) Mengajukan permintaan untuk membetulkan, mengurangkan, membebaskan ketetapan pajak dalam hal: terdapat kesalahan tulis, kesalahan hitung ataupun terdapat kesalahan menentukan dasar ketetapan. b) Mengajukan keberatan kepada inspeksi Pajak/Dierektur Jenderal Pajak apabila wajib pajak keberatan terhadap ketetapan pajak (atas jumlah yang dipakai dasar pengenaan pajak), yang harus diajukan dalam waktu tiga bulan setelah tanggal surat ketetapan pajak. ${ }^{25}$

Adapun hak dan kewajiban yang dimiliki oleh wajib pajak dikualifikasikan sebagai berikut :

a) Hak yang dimiliki Wajib Pajak antara lain :

1. Melakukan pembetulan SPT dan mengajukan permohonan penundaan penyampaian SPT;

2. Mengajukan permohonan penundaan atau pengangsuran pembayaran pajak;

3. Mengajukan permohonan perhitungan pajak yang dikenakan dalam surat ketetapan pajak;

4. Meminta pengembalian kelebihan pembayaran pajak;

${ }^{23}$ S. F. Marbun dan Mahfud MD, Pokok-Pokok Hukum Administrasi Negara, Liberty, Yogyakarta, 2011, hlm. 131-132

${ }^{24}$ H. Mustaqiem, Pajak Daerah Dalam Transisi Otonomi Daerah, Pertama, FH UII Press, Yogyakarta, 2008, hlm. 242-243

${ }^{25}$ C. S. T. Kansil, Pengantar Ilmu Hukum Dan Tata Hukum Indonesia, Kedelapan, Balai Pustaka, Jakarta, 1989, hlm. 328 
5. Mengajukan permohonan penghapusan dan pengurangan sanksi, serta pembetulan surat ketetapan pajak yang salah;

6. Memberi kuasa kepada orang untuk melaksanakan kewajiban pajaknya.

b) Kewajiban Wajib Pajak antara lain :

1. Mendaftarkan diri untuk mendapatkan Nomor Pokok Wajib Pajak (NPWP);

2. Melaporkan usahanya untuk dikukuhkan sebagai Pengusaha Kena Pajak (PKP);

3. Menghitung dan membayar sendiri pajak dengan benar;

4. Mengisi dengan benar SPT (Surat Pemberitahuan Pajak) dan memasukkan ke kantor pelayanan pajak dalam batas waktu yang telah ditentukan;

5. Menyelenggarakan pembukuan/pencatatan. ${ }^{26}$

Keberatan yang diajukan adalah mengenai materi atau isi ketetapan pajak, yaitu jumlah rugi berdasarkan ketentuan peraturan perundang-undangan perpajakan, jumlah besarnya pajak, atau pemotongan / pemungutan pajak. Yang dimaksud dengan "suatu" pada ayat ini adalah 1 keberatan harus diajukan terhadap 1 jenis pajak dan 1 Masa Pajak atau Tahun Pajak. Keberatan hanya dapat diajukan atas SKPKB, SKPKBT, SKPLB, SKPN dan pemotongan atau pemungutan oleh pihak ketiga berdasarkan ketentuan peraturan perundang-undanganperpajakan. Apabila surat keberatan tidak lengkap atau tidak memenuhi persyaratan maka tidak dianggap sebagai surat keberatan. Tanda penerimaan Surat Keberatan diberikan Direktorat Jenderal Pajak atau melalui pos tercatat menjadi bukti penerimaan Surat Keberatan tersebut bagi kepentingan Wajib Pajak. ${ }^{27}$

Apabila diminta Wajib Pajak untuk keperluan pengajuan keberatan, maka Dirjen Pajak wajib memberikan secara tertulis hal-hal yang menjadi dasar pengenaan, pemotongan, atau pemungutan pajak. Pengajuan keberatan tidak menunda kewajiban membayar pajak, dan Dirjen Pajak dalam jangka waktu paling lama 12 bulan sejak tanggal Surat Keberatan diterima, harus memberi keputusan atas keberatan yang diajukan. Apabila dalam jangka waktu yang telah ditentukan Dirjen Pajak tidak memberikan jawaban, maka keberatan dianggap diterima. Wajib Pajak membuktikan ketidakbenaran ketetapan pajak dalam hal Wajib Pajak mengajukan keberatan terhadap pajak-pajak yang ditetapkan secara jabatan. ${ }^{28}$

Surat Ketetapan Pajak secara jabatan tersebut diterbitkan karena Wajib Pajak tidak menyampaikan Surat Pemberitahuan Tahunan meskipun telah ditegur

${ }^{26}$ Mardiasmo, Perpajakan, Edisi ke-1, CV. Andi Offset, Yogyakarta, 2009, hlm. 54

${ }^{27}$ Reynold Simandjuntak, Pengaturan Penyelesaian Sengketa Pajak. (Di Tinjau Dari Aspek Keadilan), Universitas Brawijaya, Malang, 2014, hlm. 7

${ }^{28}$ Ibid. 
secara tertulis, tidak memenuhi kewajiban menyelenggarakan pembukuan, atau menolak untuk memberikan kesempatan kepada pemeriksa memasuki tempattempat tertentu yang dipandang perlu, dalam rangka pemeriksaan guna menetapkan besarnya jumlah pajak yang terutang. Apabila Wajib Pajak tidak dapat membuktikan ketidakbenaran surat ketetapan pajak secara jabatan, pengajuan keberatannya ditolak Keputusan Dirjen Pajak dapat berupa menerima seluruhnya, menerima sebagian, menolak atau menambah jumlah pajak terutang. ${ }^{29}$

Wajib pajak pun dapat mengajukan banding ke pejabat jenderal pajak, hal ini dijelaskan pada Pasal 27 ayat (1) UU No. 16 Tahun 2000 bahwa Wajib Pajak dapat mengajukan permohonan banding hanya kepada badan peradilan pajak terhadap keputusan mengenai keberatannya yang ditetapkan oleh Direktur Jenderal Pajak. ${ }^{30}$ Kemudian pemohon dapat mengajuakan banding, menurut penjelasan Pasal 31 ayat (2) UU No. 14 Tahun 2002. Sengketa Pajak yang menjadi objek pemeriksaan adalah sengketa yang dikemukakan pemohon Banding dalam permohonan keberatan yang seharusnya diperhitungkan dan diputuskan dalam keputusan keberatan. Selain itu, Pengadilan Pajak dapat pula memeriksa dan memutus permohonan Banding atas keputusan/ketetapan yang diterbitkan oleh Pejabat yang berwenang sepanjang peraturan perundang-undanganyang terkait yang mengatur demikian. ${ }^{31}$

Pada wilayah Peradilan Pajak, tidak dikenal Kasasi, sehingga bagi pihakpihak yang bersengketa yang tidak puas terhadap putusan Pengadilan Pajak (Banding) dapat mengajukan Peninjauan Kembali atas putusan Pengadilan Pajak tersebut kepada Mahkamah Agung. ${ }^{32}$ Akan tetapi, menariknya, untuk melakukan upaya hukum banding di pengadilan pajak selain syarat formil yang harus dipenuhi seperti, pertama, terhadap 1 Keputusan diajukan 1 Surat Banding. Kedua, Banding diajukan dengan disertai alasan-alasan yang jelas, dan dicantumkan tanggal diterima surat keputusan yang dibanding. Ketiga, pada Surat Banding dilampirkan salinan Keputusan yang dibanding. Selain dari persyaratan sebagaimana dimaksud dalam ayat (1), ayat (2), dan ayat (3) serta Pasal 35, dalam hal Banding diajukan terhadap besarnya jumlah Pajak yang terutang, Banding hanya dapat diajukan apabila jumlah yang terutang dimaksud telah dibayar sebesar $50 \% .33$

\footnotetext{
29 Ibid.

${ }^{30}$ Pasal 27 ayat (1) "Undang-Undang Republik Indonesia Nomor 16 Tahun 2000 tentang Perubahan Kedua Atas Undang-Undang Nomor 6 Tahun 1983 tentang Ketentuan Umum Dan Tata Cara Perpajakan” (2000).

${ }^{31}$ Pasal 31 ayat (2) Undang-Undang Republik Indonesia Nomor 14 Tahun 2002 tentang Pengadilan Pajak.

32 Marbun, Hukum Adminsitrasi..., Op. Cit., hlm. 493-494. Pajak.

33 Pasal 36 ayat (1) Undang-Undang Republik Indonesia Nomor 14 Tahun 2002 tentang Pengadilan
} 
Hal ini secara yuridis ketentuan mengenai penormaan dalam mengajukan gugatan di pengadilan pajak dapat dilihat di dalam Pasal 43 Undang-Undang Republik Indonesia Nomor 14 Tahun 2002 tentang Pengadilan Pajak, berbunyi:

1) Gugatan tidak menunda atau menghalangi dilaksanakannya penagihan Pajak atau kewajiban perpajakan;

2) Penggugat dapat mengajukan permohonan agar tindak lanjut pelaksanaan penagihan Pajak sebagaimana dimaksud dalam ayat (1) ditunda selama pemeriksaan Sengketa Pajak sedang berjalan, sampai ada putusan Pengadilan Pajak;

3) Permohonan sebagaimana dimaksud dalam ayat (2) dapat diajukan sekaligus dalam Gugatan dan dapat diputus terlebih dahulu dari pokok sengketanya;

4) Permohonan penundaan sebagaimana dimaksud dalam ayat (2) dapat dikabulkan hanya apabila terdapat keadaan yang sangat mendesak yang mengakibatkan kepentingan penggugat sangat dirugikan jika pelaksanaan penagihan Pajak yang digugat itu dilaksanakan.

Pada umumnya, dalam wilayah pengadilan umum, pengadilan agama, pengadilan PTUN dan pengadilan Militer, dikenal upaya banding di pengadilan tinggi dan upaya kasasi di Mahkamah Agung apabila putusan di tingkat pertama dalam menemukan fakta-fakta di dalam persidangan tidak puas menerima dari putusan hakim (judex factie), sehingga untuk menilai atau mengoreksi dari putusan tingkat pertama dan tingkat kedua tersebut MA menjadi jalan bagi masyarakat yang menginginkan kepastian hukum berupa putusan MA yang menilai dari segi yuridisnya (judex juris). Kelemahan ini terlihat pada pengadilan pajak sebagai badan peradilan tingkat pertama dan sekaligus tingkat terakhir, atau singkatnya, meskipun pengadilan pajak tidak memberikan putusan yang berkeadilan bagi wajib pajak maka menjadi keharusan si wajib pajak untuk tetap melaksanakan putusan tersebut.

Pada bagian Penjelasan UU Nomor 14 Tahun 2002 terkait hal di atas, diuraikan bahwa Pengadilan Pajak yang diatur dalam ketentuan tersebut bersifat khusus menyangkut acara penyelenggaraan persidangan sengketa perpajakan. Hal-hal yang perlu diperhatikan berkaitan dengan kekhususan Pengadilan Pajak adalah sebagai berikut.

1. Sidang peradilan pajak pada prinsipnya dilaksanakan secara terbuka, namun dalam hal tertentu dam khusus guna menjaga kepentingan pemohon banding atau tergugat, sidang dapat dinyatakan tertutup, sedangkan pembacaan Pengadilan Pajak dilaksanakan dalam sidang yang terbuka untuk umum;

2. Penyelesaian sengketa perpajakan memerlukan tenaga-tenaga hakim khusus yang mempunyai keahlian di bidang perpajakan dan berijazah Sarjana Hukum atau sarjana lain; 
3. Sengketa yang diproses dalam Pengadilan Pajak khusus menyangkut sengketa perpajakan;

4. Putusan Pengadilan Pajak memuat penetapan besarnya terutang dari Wajib Pajak, berupa hitungan secara teknis perpajakan, sehingga Wajib Pajak langsung memperoleh kepastian hukum tentang besarnya pajak terutang yang dikenakan kepadanya. Sebagai akibat jenis putusan Pengadilan Pajak, di samping jenis-jenis putusan yang umum diterapkan pada peradilan umum, juga berupa mengabulkan sebagian, mengabulkan seluruhnya, atau menambah jumlah pajak yang masih harus dibayar. ${ }^{34}$

Sebagai konsekuensi dari kekhususan tersebut di atas, UU Nomor 14 Tahun 2002 mengatur pula hukum acara tersendiri untuk menyelenggarakan Pengadilan Pajak. Perihal hukum acara ini diatur dalam Bab IV tentang Hukum Acara.

Pihak-pihak yang berperkara dapat mengajukan peninjauan kembali atas putusan Pengadilan Pajak kepada Mahkamah Agung, dengan ketentuan: 1) Permohonan peninjauan kembali disampaikan kepada Mahkamah Agung melalui Pengadilan Pajak. 2) Permohonan peninjauan kembali tersebut hanya dapat diajukan 1 kali. 3) Permohonan peninjauan kembali tidak menangguhkan atau menghentikan pelaksanaan putusan Pengadilan Pajak. 4) Permohonan peninjauan kembali dapat dicabut sebelum diputus, dan dalam hal sudah dicabut permohonan peninjauan kembali tersebut tidak dapat diajukan lagi. Hukum acara yang berlaku pada pemeriksaan peninjauan kembali adalah hukum acara pemeriksaan peninjauan kembali sebagaimana dimaksud dalam UU Nomor 14 tahun 1985 sebagaimana telah diubah dengan UU Nomor 3 Tahun 2009 tentang Mahkamah Agung. ${ }^{35}$ Mahkamah Agung memeriksa dan memutus permohonan peninjauan kembali pada tingkat pertama dan terakhir atas putusan Pengadilan yang telah memperoleh kekuatan hukum tetap berdasarkan alasan-alasan yang diatur dalam Bab IV Bagian Keempat Undang-Undang ini. ${ }^{36}$

Sebagai perbandingan (comparation) Mahkamah Agung di negara Belanda dengan Indonesia atas sengketa pajak yang telah diputuskan di tingkat otoritas pajak, wajib pajak dapat mengajukan banding kepada salah satu dari lima Pengadilan Pajak (Tax Court) yang ada di Belanda. Pada dasarnya, secara teknis, Tax Court ini merupakan cabang atau bagian dari lima regional Courts of Appeal (Gerechtshoven) yang menyidangkan sengketa banding uang berasal dari sembilan

34 Rizal Muchtasar, "Pengadilan Pajak Di Indonesia Sebagai Solusi Sengketa Pajak (Aturan Dan Pelaksanaannya)," Docplayer, 2018, https://docplayer.info/50204117-Pengadilan-pajak-di-indonesia-sebagaisolusi-sengketa-pajak-aturan-dan-pelaksanaannya-oleh-rizal-muchtasar-1-intisari.html. akses 11 Juni 2020

35 BPHN, "Naskah Akademik RUU Tentang Perubahan Atas UU Nomor 14 Tahun 2002 tentang Pengadilan Pajak," 2002.

36 Pasal 34 "Undang-Undang Republik Indonesia Nomor 14 Tahun 1985 tentang Mahkamah Agung" (2013). 
belas District Courts (Rechtbanken). Terhadap putusan Tax Court dapat diajukan banding kepada Supreme Court (dua dari empat divisi Supreme Court yang menangani kasus sengketa perpajakan). Dalam kasus penting, "the advocates general" (official advisers) dari Supreme Court akan memberikan opini sebelum diterbitkannya putusan. Di Belanda, apabila Mahkamah Agung memenangkan wajib pajak dan ketika otoritas pajak Belanda tidak setuju dengan putusan Mahkamah Agung. Akan tetapi, apabila Mahkamah Agung tetap memenangkan wajib pajak, maka otoritas pajak Belanda akan mengubah ketentuan perpajakannya. ${ }^{37}$

Di Indonesia, eksekusi putusan pengadilan pajak langsung dapat dilaksanakan dengan tidak memerlukan lagi keputusan pejabat yang berwenang, kecuali peraturan perundang-undangan mengatur lain. Putusan yang mengabulkan sebagian atau seluruh banding, maka kelebihan pembayaran pajak dikembalikan dengan ditambah imbalan bunga sebesar $2 \%$ sebulan paling lama 24 bulan. ${ }^{38}$

Mengenai acara upaya hukum luar biasa tersebut, maka pengajuan Peninjauan Kembali di Mahkamah Agung, sebagaimana tugas dan wewenangnya memeriksa dan memutus, a. permohonan kasasi; b. sengketa tentang kewenangan mengadili; c. permohonan peninjauan kembali putusan Pengadilan yang telah memperoleh kekuatan hukum tetap. ${ }^{39}$ Sedangkan waktu bagi Mahkamah Agung untuk memeriksa dan memutus permohonan peninjauan kembali adalah:

a. Dalam jangka waktu 6 bulan sejak permohonan peninjauan kembali diterima oleh Mahkamah Agung telah mengambil putusan, dalam hal Pengadilan Pajak mengambil putusan melalui pemeriksaan acara biasa;

b. Dalam jangka waktu 1 bulan sejak permohonan peninjauan kembali diterima oleh Mahkamah Agung telah mengambil putusan, dalam hal Pengadilan Pajak mengambil putusan melalui pemeriksaan acara cepat.

Proses peninjauan kembali yang dimohonkan ke Mahkamah Agung berdasarkan ketentuan UU Nomor 14 Tahun 2002 oleh salah satu pihak yang berperkara dapat di lihat pada jenjang penyelesaian sengketa pajak seperti di bawah ini:

37 Darussalam, "Kedudukan Pengadilan Pajak Di Berbagai Negara," Observation \& Research Of Taxation (Ortax), 2009, https:/ $/$ www.ortax.org/ortax $/$ mod $=$ issue\&page $=$ show\&id $=41 \&$ list $=\& q=\&$ hal $=6 \#$ _ftn6. Akses 11 Juni 2020

38 Marbun, Hukum Adminsitrasi..., Op. Cit., hlm. 493.

39 Pasal 28 ayat (1) Undang-Undang Republik Indonesia Nomor 14 Tahun 1985 tentang Mahkamah Agung. 
Tabel. 3 Jenjang Penyelesaian Sengketa Pajak

Surat Uraian diajukan dalam waktu 3 bulan oleh Terbanding

- PK hanya 1 kali di MA

- 3 Bulan terhitung sejak diketahuinya kebohongan atau tipu muslihat

- 6 bulan sejak permohonan PK diterima

Kantor Pelayanan Pajak/ Direktorat Pajak

\section{Sengketa}

Para pihak dapat di dampingi atau diwakili oleh satu atau lebih kuasa hukum dengan Surat Kuasa Khusus

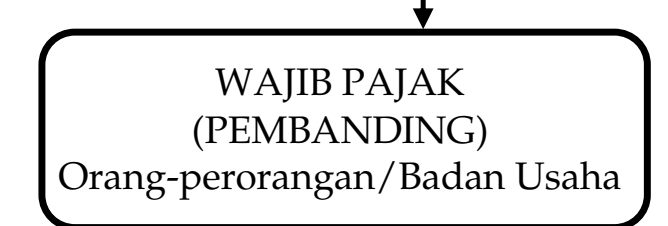

WP dalam 3 bulan diajukan dengan lampiran Surat Uraian Banding atau Surat Tanggapan

- 1 Surat Banding

- Surat Banding dilampirkan salinan Keputusan yang dibanding

- Jumlah terutang telah membayar 50\%

Undang-Undang Pengadilan Pajak adalah mengenai sifat putusan Pengadilan Pajak yang merupakan putusan terakhir dan dapat langsung diajukan Peninjauan Kembali ke Mahkamah Agung (selanjutnya disingkat MA). Hal ini sebenarnya selain memangkas hak WP juga bertentangan dengan PTUN yang mana atas putusannya masih dapat diajukan Kasasi dan baru setelah itu Peninjauan Kembali. Hal ini juga ditolerir oleh MK dengan dalil bahwa upaya Kasasi maupun Peninjauan Kembali juga sama-sama ditangani MA. Dalil MK ini tampaknya mengabaikan fakta bahwa dalam upaya Peninjauan Kembali terdapat beberapa pembatasan (adanya syarat-syarat sebagaimana diatur dalam Pasal 91 UU PP), sementara dalam upaya Kasasi tidak ada batasan demikian. ${ }^{40}$

Sebagaimana dalam hal permohonan peninjauan kembali hanya dapat diajukan berdasarkan alasan-alasan sebagai berikut:

a. Apabila putusan Pengadilan Pajak didasarkan pada suatu kebohongan atau tipu muslihat pihak lawan yang diketahui setelah perkaranya diputus atau didasarkan pada bukti-bukti yang kemudian oleh hakim pidana dinyatakan palsu;

b. Apabila terdapat bukti tertulis baru yang penting dan bersifat menentukan, yang apabila diketahui pada tahap persidangan di Pengadilan Pajak akan menghasilkan putusan yang berbeda; 
c. Apabila telah dikabulkan suatu hal yang tidak dituntut atau lebih dari pada yang dituntut, kecuali yang diputus berdasarkan Pasal 80 ayat (1) huruf $b$ dan huruf $c$;

d. Apabila mengenai suatu bagian dari tuntutan belum diputus tanpa dipertimbangkan sebab-sebabnya; atau

e. Apabila terdapat suatu putusan yang nyata-nyata tidak sesuai dengan ketentuan peraturan perundang-undanganyang berlaku. ${ }^{41}$

Apabila dicermati hukum acara penyelesaian sengketa pajak di Pengadilan Pajak juga sangat berbeda dengan hukum acara PTUN sebagaimana dijelaskan dalam sub bagian berikut ini. Hukum acara ini menimbulkan pertanyaan sensitif mengenai apakah kedudukan Pengadilan Pajak merupakan lex specialis dari PTUN. Ketiga, Pasal 43 ayat (6) huruf c yang menyebutkan bahwa dalam hal putusan Banding diajukan permohonan Peninjauan Kembali, imbalan bunga diberikan apabila Putusan Peninjauan Kembali telah diterima oleh DJP dari MA. Berdasarkan ketentuan-ketentuan tersebut, jelas sekali bahwa hakikat Putusan Peninjauan Kembali sudah bukan lagi hasil dari upaya hukum luar biasa. Ketentuan-ketentuan ini sebenarnya tidak terlalu adil dalam aspek pemenuhan hak WP, mengingat waktu penyelesaian sengketa Peninjauan Kembali di MA yang dapat memakan waktu yang relatif lama. Hak WP bisa saja tidak terlindungi apabila sengketa terkait dengan upaya penagihan aktif yang dilakukan oleh DJP, karena dalam PP-74 Tahun 2011 sama sekali tidak diatur bahwa upaya penagihannya akan ditunda hingga dikeluarkannya Putusan Peninjauan Kembali. ${ }^{42}$

Ketentuan dalam Pasal 77 tersebut tidak memungkinkan adanya peradilan kasasi oleh Mahkamah Agung dalam penyelesaian sengketa pajak. Hal ini bertentangan dengan Pasal 11 ayat (2) Undang-Undang Nomor 4 Tahun 2004 yang menyatakan, bahwa Mahkamah Agung mempunyai kewenangan mengadili pada tingkat kasasi terhadap putusan yang diberikan pada tingkat terakhir oleh pengadilan di semua lingkungan peradilan yang berada di bawah Mahkamah Agung. Pasal 80 ayat (1) Putusan Pengadilan Pajak dapat berupa:
a) Menolak;
b) Mengabulkan sebagian atau seluruhnya;
c) Menambah Pajak yang harus dibayar;
d) Tidak dapat diterima;
e) Membetulkan kesalahan tulis dan/atau kesalahan hitung; dan/atau
f) Membatalkan

\footnotetext{
41 Pasal 91 Undang-Undang Republik Indonesia Nomor 14 Tahun 2002 tentang Pengadilan Pajak.

42 Juli, "Hak Dan..., Loc. Cit.
} 
Seharusnya penertiban pengadilan khusus seperti pengadilan pajak harus melebur dalam kesatuan kekuasaan kehakiman di Indonesia dengan tidak menjadi kulit luar dari Mahkamah Agung sebagai kekuasaan yang merdeka untuk menyelenggarakan peradilan guna menegakkan hukum dan keadilan (vide; Pasal 24 ayat (1) UUD 1945). Hal ini mengundang polemik dalam sistem peradilan Indonesia. Sebagaimana Bagir Manan berpesan, badan peradilan khususnya perlu diperbaharui. Pembaharuan mencakup antara lain menertibkan kembali berbagai lingkungan badan peradilan, seperti badan peradilan pajak yang menyimpang dari sistem badan peradilan yang ada. Kalau memang akan dikembangkan berbagai badan peradilan khusus sebagai lingkungan yang mandiri (pajak, perburuhan), perlu diberi dasar dalam Undang-Undang yang menjadi dasar pengaturan kekuasaan kehakiman. Dengan cara itu akan didapati sistem tertib. ${ }^{43}$

\section{Penutup}

Mahkamah Agung memiliki peran dalam melakukan pembinaan dan pengawasan terhadap pengadilan pajak. Menurut UU Nomor 14 Tahun 2002 tentang Pengadilan Pajak. MA masih memiliki peran yang besar dalam mengawasi tugas peradilan dan tingkah laku hakim. Namun, dalam hal pengangkatan dan pangkat dan dalam struktural peradilan, administrasi, pengorganisasian dan finansial masih menjadi kewenangan kementerian keuangan dan direktorat jenderal pajak dalam hal ini masuk dalam lingkungan eksekutif.

Terkait kewenangan MA dalam beracara sebagaimana dikenal upaya hukum biasa, yakni banding di pengadilan tinggi dan kasasi di MA, pada pengadilan pajak tidak mengenal istilah tersebut. hanya saja upaya luar biasa yang dilakukan dapat diajukan peninjauan kembali dengan ketentuan hanya dapat dilakukan 1 kali. Artinya dalam judex faxtie MA tidak memiliki kewenangan apapun dalam mengoreksi putusan tingkat pertama dan kedua dalam pengadilan pajak.

Melihat penjabaran di bagian sebelumnya, perlu memang kiranya adanya pembaharuan dalam Undang-Undang peradilan pajak dalam hal memutus sengketa pajak di tingkat kasasi sehingga adanya kedudukan dan kewenangan lebih terhadap MA dalam memeriksa, mengadili dan memutus sengketa pajak dalam wilayah judex juris dengan tujuan memberikan keadilan hukum bagi Wajib Pajak untuk melakukan upaya hukum biasa, hal ini dikarenakan upaya peninjauan kembali memiliki syarat cukup berat berdasarkan Pasal 91 UndangUndang Republik Indonesia Nomor 14 Tahun 2002 tentang Pengadilan Pajak.

\footnotetext{
${ }^{43}$ Bagir Manan, Teori Dan Politik Konstitusi, Pertama, FH UII Pers., Yogyakarta, 2003, hlm. 112-113.
} 


\section{Daftar Pustaka}

\section{Buku}

BPHN. "Naskah Akademik RUU Tentang Perubahan Atas UU Nomor 14 Tahun 2002 tentang Pengadilan Pajak," 2002.

C. S. T. Kansil, Pengantar Ilmu Hukum Dan Tata Hukum Indonesia, Kedelapan: Balai Pustaka, Jakarta, 1989.

Dillah, Suratman dan Philips, Metode Penelitian Hukum, Ketiga, Alfabeta, Bandung, 2015.

Huda, Ni'Matul, Hukum Tata Negara Indonesia Edisi Revisi, PT Raja Grafindo Persada, Jakarta, 2014.

Jan, Tjia Siauw. Pengadilan Pajak Upaya Kepastian Hukum Dan Keadilan Bagi Wajib Pajak. Ke-I, PT ALUMNI, Bandung, 2013.

Manan, Bagir, Teori Dan Politik Konstitusi, Pertama, FH UII Pers, Yogyakarta, 2003.

Marbun, S.F., Asas-Asas Umum Pemerintahan Yang Layak, FH UII Press, Yogyakarta, 2014.

Hukum Adminsitrasi Negara I (Administrative Law I), FH UII Press, Yogyakarta, 2018.

dan Mahfud MD, Pokok-Pokok Hukum Administrasi Negara, Liberty, Yogyakarta, 2011.

Mardiasmo, Perpajakan, Edisi ke-1, CV. Andi Offset, Yogyakarta, 2009.

Mustaqiem, H., Pajak Daerah Dalam Transisi Otonomi Daerah, Pertama, FH UII Press, Yogyakarta, 2008.

Simandjuntak, Reynold, Pengaturan Penyelesaian Sengketa Pajak (Di Tinjau Dari Aspek Keadilan), Universitas Brawijaya, Malang, 2014.

Sunggono, Bambang. Metode Penelitian Hukum, Ke 14, PT Grafindo Persada, Jakarta, 2013.

Wiwoho, Jamal, Membangun Model Penyelesaian Sengketa Pajak Yang Berkeadilan, Lembaga Pengembangan Pendidikan UNS Dan UPT Penerbitan dan Percetakan UNS Press, Surakarta, 2008.

\section{Jurnal}

Adam Setiawan. "Eksistensi Lembaga Pengawasan Pengelolaan Keuangan Negara." Jurnal Hukum \& Pembangunan 49, No. 2 (2019): 265-78.

Ahmad Basuki, "Pengawasan Terhadap Penyelenggaraan Kekuasaan Kehakiman Sebagai Upaya Dalam Mewujudkan Akuntabilitas Peradilan Pidana." Perspektif 3, No. 1 (2013), 4-7.

Wan Juli, "Hak Dan Kewajiban Wajib Pajak Dalam Penyelesaian Sengketa Perpajakan Di Pengadilan Pajak." Perspektif XIX, No. 3 (2014): 190-200.

Afdol Sylvia Setjoatmadja, "Kedudukan, Eksistensi Dan Indepedensi Pengadilan Pajak Dalam Kekuasaaan Kehakiman Di Indonesia." Jurnal Hukum Bisnis 1, No. 1 (2015). 
Agus S. Suryadi, "Hukum Pajak Menghendaki Pemungkutan Hukum." Law Review V, No. I (2005): 338-52.

Heru Suyanto, "Sengketa Perpajakan Dalam Perspektif Kekuasaan." Yuridis 2, No. 1 (2015): 95-110.

\section{Makalah}

Manan, Bagir, "Prasyarat Kemerdekaan Kekuasaan Kehakiman, Makalah Disampaikan Kuliah Umum Mahasiswa Magister Ilmu Hukum Universitas Islam Indonesia." Yogyakarta, 2018.

\section{Peraturan Perundang-undangan}

Undang-Undang Republik Indonesia Nomor 14 Tahun 1985 tentang Mahkamah Agung (2013).

Undang-Undang Republik Indonesia Nomor 14 Tahun 2002 tentang Pengadilan Pajak (2002).

Undang-Undang Republik Indonesia Nomor 16 Tahun 2000 tentang Perubahan Kedua Atas Undang-Undang Nomor 6 Tahun 1983 tentang Ketentuan Umum Dan Tata Cara Perpajakan (2000).

\section{Media online}

Darussalam. "Kedudukan Pengadilan Pajak Di Berbagai Negara." Observation \& Research of Taxation (Ortax), 2009. https://www.ortax.org/ortax/?mod $=$ issue\&page $=$ show\&id=41\&list $=\& q=\& h a l=6 \# \_f t n 6$.

Muchtasar, Rizal. "Pengadilan Pajak Di Indonesia Sebagai Solusi Sengketa Pajak (Aturan Dan Pelaksanaannya)." Docplayer, 2018. https://docplayer.info/ 50204117-Pengadilan-pajak-di-indonesia-sebagai-solusi-sengketa-pajakaturan-dan-pelaksanaannya-oleh-rizal-muchtasar-1-intisari.html. 